\title{
РОЛЬ ВИВЧЕННЯ ДИСЦИПЛІНИ “СЕСТРИНСЬКА ПРАКТИКА” НА КАФЕДРІ ПРОПЕДЕВТИКИ ВНУТРІШНЬОЇ МЕДИЦИНИ В ПРОЦЕСІ ФОРМУВАННЯ ЛІКАРЯ-СПЕЦІАЛІСТА
}

\author{
О. Б. Молодовець \\ ДВНЗ “Івано-Франківський національниймедичний університет”
}

O. B. Molodovets

\author{
SHEI "Ivano-Frankivsk National Medical University"
}

\begin{abstract}
Виробнича практика 3 “Сестринської справи” (терапія) є обов'язковим елементом поетапного формування лікаряспеціаліста. Перелік обов'язкових практичних навиків регламентований Програмою сестринської виробничої практики для вищих медичних закладів освіти України III-IV рівнів акредитації і складений для спеціальності 7.110101 “Лікувальна справа” напряму підготовки “Медицина” відповідно до освітньо-кваліфікаційної характеристики та освітньопрофесійної програми підготовки фахівців, затверджених наказом МОН України від 16.04.2003 р. № 239, та навчального плану, затвердженого наказом МОЗ України від 31.01.2005 p. № 52. Алгоритми виконання кожного з належних навиків та ретельне опрацювання їх на муляжах навчально-тренінгового центру є етапом рівнів “знаю-вмію-володію”. Можливість проведення виробничої практики на клінічних базах (терапевтичних стаціонарах) дозволяє не тільки досконало оволодіти практичними навиками, але й формує етичні засади майбутніх професійних стосунків “лікар - медсестра”, “лікар пацієнт”, клінічне мислення, формат майбутньої організації лікувального процесу.
\end{abstract}

Industrial practice of "Nursing" (therapy) is compulsory element of step-by-step formation of doctor-specialist. The list of compulsory practical skills is regulated by the Program of Nursing Industrial Practice for the higher medical establishments of the III-IV levels of accreditation and is composed for specialists 7.110101 "Medicative course" of the course of the preparation "Medicine" according to educational-qualification characteristic and educational-professional program of the specialists preparation approved by the Order of Ministry of Education of Ukraine of 16.04.2003 № 239 and curriculum approved by the Order of ministry of Health of 31.01.2005 № 52. Algorithms of fulfillment of every of appropriate skills and accurate development of them on moulage of educational-training centre is a stage of the level "know-can-able to use". The possibility of the carrying out the industrial practice in clinic bases (therapeutic hospitals) allows not only to develop the practical skills perfectly but to form ethic base of future relationships "doctor-nurse", "doctor-patient", clinical thinking, format of future organization of medicative process.

Вступ. У 2005 році відбувся процес офіційного входження України в єдиний Європейський освітній простір через підписання Болонської декларації. Це привело до певних змін та перегляду аспектів організації навчального процесу, вимагало певної адаптації та перебудови надання освіти у вищих медичних навчальних закладах України [1]. Згідно з реформуванням, виробничу практику з медсестринства було перенесено на вивчення за кредитно-модульною системою у V семестрі. Для засвоєння даного курсу на кафедрі пропедевтики внутрішньої медицини відведено 40 год. Програма сестринської виробничої практики для вищих медичних закладів освіти

(C) О. Б. Молодовець
України III-IV рівнів акредитації складена для спеціальності 7.110101 “Лікувальна справа" напряму підготовки “Медицина" відповідно до освітньо-кваліфікаційної характеристики та освітньо-професійної програми підготовки фахівців, затверджених наказом МОН України від 16.04.2003 р. № 239, та навчального плану, затвердженого наказом МОЗ України від 31.01.2005 p. № 52. Це створило безпрецедентні умови для більш повного вивчення теоретичної частини, та грунтовнішого засвоєння, під наглядом викладача, практичних навичок по даній дисципліні.

Основна частина. Одним із найважливіших етапів у системі професійної підготовки майбутнього лікаря, важливою ланкою формування професійних умінь і засвоєння навичок медичної професії є система прак- 
тичної підготовки [2]. Практична підготовка дозволяє студенту набути досвід професійної діяльності, сформувати у нього професійні навички, які він, у подальшому, зможе застосовувати у своїй роботі. Практика дозволяє студенту безпосередньо зануритись у середовище майбутньої професії - це модель майбутньої роботи фахівця. Вона дозволяє закріпити навики, здобуті під час аудиторних занять, навчитись працювати в колективі, оволодіти правилами медичної етики та деонтології. Бездоганне оволодіння майбутнім лікарем навиків медсестринства в подальшому дозволить йому більш чітко вимагати у середнього медичного персоналу виконання будь-якої маніпуляції, що буде благотворно впливати на мікроклімат в колективі, сприяти формуванню професійних стосунків лікар - медсестра. Саме в ході практичної діяльності формуються риси, якими повинен володіти кваліфікований медичний працівник: професіоналізм, милосердя, терпіння, цілеспрямованість. Зазначимо, що позитивні риси не є природженими чи незмінними, вони розвиваються внаслідок виховання і практичного досвіду. Майбутній медик за допомогою своїх викладачів і старших товаришів виховує в собі любов до своєї справи, шанобливе ставлення до хворого. Розуміння обов' язку і співчуття, бажання допомогти є силою, яка допомагає долати численні перешкоди у професійному становленні медика [3].

Цикл “Сестринської практика” (терапія) для студентів лікувального та педіатричного факультетів проходить на базі кафедри пропедевтики внутрішньої медицини. Він забезпечує безперервність та послідовність здобуття студентами достатнього обсягу практичних знань та вмінь. Оскільки для студентів третього курсу це є одна з перших клінічних кафедр і досвід роботи у клініці у них ще малий, то велика роль при вивченні цієї дисципліни відводиться викладачу. Важливими складовими проведення кожного тематичного заняття є усне опитування [4], контроль засвоєння практичних навиків, вирішення ситуаційних задач та тестових завдань. Ситуаційні задачі та тестові запитання складені працівниками нашої кафедри з урахуванням ключових питань теми згідно 3 календарно-тематичним планом занять. Велике значення при проведенні аудиторних занять відводиться усному опитуванню, під час якого студенту надається можливість розвивати своє клінічне мислення, вчитись правильно формулювати свої думки, відстоювати свою позицію, аналізувати, дискутувати, тобто формуватися як лікар-спеціаліст. Під час усного опитування важливу увагу звертають на розбір практичних навиків, вказуючи на нюанси, які недо- статньо висвітлені в підручнику або викликають певні труднощі при їх засвоєнні. Застосовується дискусія 3 включенням в обговорення проведення певної маніпуляції якомога більшою кількістю студентів, чітко обговорюються показання, протипоказання та доцільність проведення певних процедур чи маніпуляцій, наочно демонструються документи, які необхідно вміти заповнювати, та обговорюються правила їх заповнення. Студенти часто самі спонукають до більш детального розбору матеріалу, який їм безпосередньо знадобиться для подальшого удосконалення своїх медичних знань.

Велика увага при засвоєнні даного циклу відводиться відпрацюванню практичних навиків, які затверджені робочою програмою. В програму практики увійшло обов' язкове засвоєння навиків, які переважно являють собою клінічні маніпуляції. Слід зазначити, що чітке розмежування маніпуляцій, диференційований облік їх засвоєння готує студента до практичноорієнтованого державного іспиту, в основі якого лежить саме демонстрація рівня оволодіння практичними навиками. Тому для засвоєння практичних навиків на кафедрі пропедевтики внутрішньої медицини розроблені алгоритми виконання кожної маніпуляції, передбаченої програмою. Обов'язковим є спершу усний розбір виконання навику, а в подальшому демонстрація виконання на фантомах та за допомогою іншого дидактичного матеріалу.

3 перших занять також студенти ознайомлюються та вчаться заповнювати документацію, яка ведеться у різних підрозділах стаціонару, у тому числі старшою медичною сестрою, постовими та маніпуляційними медичними сестрами. При вивченні різноманітних інструментальних маніпуляцій, методів підготовки хворого до різноманітних методів дослідження, зондових методів дослідження та техніки реєстрації ЕКГ студенти користуються обладнанням навчально-тренінгового центру кафедри внутрішньої медицини № 3 та медсестринства. У цьому є численні переваги, оскільки такий формат дозволяє охопити стовідсоткове опрацювання студентами того чи іншого практичного навику. Окрім того, що зали обладнані усім необхідним обладнанням, в кожному 3 них наявні алгоритми виконання тієї чи іншої процедури, що дозволяє студенту більш чітко та ретельно іiі засвоїти.

Основний час практики відводиться для роботи в стаціонарі, де студенти знайомляться 3 роботою різних підрозділів, із особливостями роботи постової, маніпуляційної медичної сестри; під наглядом медсестри чи викладача проводять різноманітні сес- 
тринські маніпуляції, вчаться користуватись листком призначень, готують хворих до різноманітних досліджень. Завдяки злагодженій роботі кафедри та терапевтичних відділень стаціонару нам вдається залучити студентів до оволодіння практичними навиками біля ліжка хворого, що веде до глибшого формування в студента професійних умінь.

Не менш важлива роль при проходженні циклу “Сестринська практика” відводиться формуванню в студентів якостей, які необхідні для професійної підготовки майбутніх фахівців медичної сфери. Раціональним є використання в даних цілях позицій соціології професіоналізму [5]. Дане поняття включає в себе професіоналізм у діяльності, що грунтується на формуванні професійної компетентності, професійних навичок і вмінь студентів; професіоналізм в особистості, що передбачає динамічний розвиток здібностей, професійно важливих індивідуально-ділових якостей, творчого інноваційного потенціалу, мотивації досягнень; нормативності діяльності і поведінки, що потребує формування професійної та моральної системи регуляції поведінки, діяльності і стосунків майбутніх медиків в умовах, наближених до реальної професійної діяльності, продуктивної “Я-концепції”, коли студент в умовах змодельованих професійних ситу- ацій має змогу здійснити професійну самоідентифікацію $з$ метою визначення відповідності свого професійного становлення суспільним вимогам і фаховим стандартам.

Висновки: 1. Впровадження модульно-рейтингової технології при проходженні практики під час навчального семестру дає можливість оцінити стан навчально-пізнавальної роботи студентів 3 дисципліни, а також мотивувати студентів систематично займатися впродовж навчального семестру та підвищує контроль викладача за регулярністю та правильністю засвоєння матеріалу.

2. Виробнича практика “Сестринська справа” (терапія) дозволяє: удосконалити оволодіння регламентованими практичними навиками біля ліжка хворого; самостійне заповнення та ведення сестринської медичної документації; безпосередню участь у підготовці і виконанні діагностичних маніпуляцій та процедур.

3. Належне оволодіння практичними навиками $€$ етапом підготовки до державного практично-орієнтованого іспиту “біля ліжка хворого”.

4. Виробнича практика також покращує комунікативні вміння студентів, формує повноцінного лікаряорганізатора лікувального процесу.

\section{Списоклітератури}

1. Пидаев А. В. Болонский процесс в Европе / А. В. Пидаев, В. Г. Передерий. - Одесса : Одес. гос. ун-т, 2004. -192 с.

2. Волосовець О. П. Питання якості освіти у контексті впровадження засад Болонської декларації у вищій медичній школі / О. П. Волосовець // Медична освіта. - 2005. №2. - С. 12-16.

3. Організація роботи студентів під час вивчення дисципліни “Сестринська практика” на кафедрі пропедевтики пе- діатрії / А. П. Юрцева, Б. М. Павликівська, В. Б. Мотрюк [та ін.] // Медична освіта. -2012. -№ 3 (додаток). -С. 214-217.

4. Мазепа X. Історико-педагогічні аспекти підготовки медиків / Х. Мазепа // Вісник Львівського університету. 2004. - Вип. 18.- С. 37-43.

5. Погрібна В. Л. Соціологія професіоналізму : монографія / В. Л. Погрібна. - К. : Алерта : КНТ : ЦУЛ, 2008. -336 с.

Отримано 04.02.15 